\title{
Hepatitis C Virus NS3-NS4A Protease Inhibitors from the Endophytic Penicillium chrysogenum Isolated from the Red Alga Liagora viscida
}

Usama W. Hawas ${ }^{\mathrm{a}, \mathrm{b}, *}$, Ali M. El-Halawany ${ }^{\mathrm{c}, \mathrm{d}}$, and Eman F. Ahmed ${ }^{\mathrm{e}}$

a Marine Chemistry Department, Faculty of Marine Sciences, King Abdulaziz University, P. O. Box 80207, Jeddah 21589, Kingdom of Saudi Arabia. Fax: +966-2-6401747.

E-mail: hawasusama@yahoo.com

b Phytochemistry and Plant Systematic Department, National Research Centre, 12311-Dokki, Cairo, Egypt

c Pharmacognosy Department, Faculty of Pharmacy, Cairo University, Kasr El-Aini St. 11562, Cairo, Egypt

d Faculty of Pharmacy, King Abdulaziz University, P. O. Box 80207, Jeddah 21589, Kingdom of Saudi Arabia

e Chemistry of Natural and Microbial Products Department, National Research Centre, 12311-Dokki, Cairo, Egypt

* Author for correspondence and reprint requests

Z. Naturforsch. 68c, 355-366 (2013); received November 13, 2012/September 25, 2013

Hepatitis C virus (HCV) NS3-NS4A protease is an attractive target for anti-HCV agents because of its important role in replication. In this work, we demonstrated that the ethyl acetate extract of the endophytic fungus Penicillium chrysogenum exhibited a potent activity against HCV NS3-NS4A protease with an $\mathrm{IC}_{50}$ value of $20 \mu \mathrm{g} / \mathrm{ml}$. The fungus was isolated from the red alga Liagora viscida and identified by its morphology and 18S rDNA. Largescale fermentation of the fungus in Czapek's peptone liquid medium followed by chromatographic purification of the active extract from the liquid medium allowed the isolation of twelve known metabolites. The biological properties of the isolated compounds were explored for anti-HCV protease as well as antimicrobial and anticancer activities. A computational docking study of the active isolated compounds against HCV protease was used to formulate a hypothetical mechanism for the inhibitory activity of the active compounds on the tested enzymes.

Key words: Red algae, Liagora viscida, Penicillium chrysogenum, HCV NS3-NS4A Protease

\section{Introduction}

Chronic hepatitis $\mathrm{C}$ virus (HCV) infection is a global problem due to both the lack of an effective therapy and the difficulties in developing a protective vaccine. Thus, there is an urgent need for new, specifically targeted therapies for the treatment of chronic HCV infection. Hepatitis C virus protease (HCV PR) inhibition is considered to be one of the important targets for designing drugs for HCV treatment (Tsantrizos, 2008). HCV NS3-NS4A is a heterodimeric serine protease responsible for the proteolytic processing of four out of five junctions between nonstructural protein regions along the $\mathrm{HCV}$ polyprotein (De Francesco and Carfi, 2007). It also plays a role in silencing the host's antiviral immune response by interfering with interferon production as a natural defence against infections (Gale and Foy, 2005).
In recent years, numerous metabolites possessing uncommon structures and potent bioactivities have been isolated from strains of fungi collected from diverse environments, such as soils, animals, plants, and sediments (Laatsch, 2006). Penicillium chrysogenum is an important filamentous fungus because of its ability to produce large amounts of penicillin (Elander, 2003).

The secondary metabolites of $P$. chrysogenum include various penicillins, chrysogine, xanthocillins, secalonic acids, sorrentanone, and PR toxin (De Hoog et al., 2000). Recently, many bioactive metabolites were reported from different cultures of $P$. chrysogenum which exhibited broad biological activities, such as xanthoviridicatins $\mathrm{E}$ and $\mathrm{F}$ (HIV-1 integrase inhibitory activity) (Singh et al., 2003), sorbicillinoid alkaloids (sorbicillactones $\mathrm{A}$ and B; anti-HIV and strong cytotoxic activity) (Bringmann et al., 2005), chrysogenamide A 
(neuroprotective effect on SH-SY5Y cells) (Lin et al., 2008), glycerol derivatives, and penicitides A-C with cytotoxic activities against the human hepatocellular liver carcinoma cell line (Gao et al., 2011), as well as $16 \beta$-acetoxy-tetrahydroxy-22ergostene and hypocrellin $\mathrm{B}$ or $\mathrm{C}$ as antifungal agents (Meng et al., 2011).

In the course of a program aiming at the isolation of bioactive natural products from marine endophytic fungi, $P$. chrysogenum was isolated from the inner tissues of the Egyptian Red Sea alga Liagora viscida (Forsskål) C. Agardh. Here, we describe the isolation and structure elucidation of the secondary metabolites from the culture medium of the isolated fungus. The organic extract and the isolated pure compounds were evaluated for their antimicrobial and anticancer activities, as well as for their inhibitory effect on HCV NS3-NS4A protease using a SensoLyte ${ }^{\mathrm{TM}}$ $520 \mathrm{HCV}$ protease assay kit.

\section{Results and Discussion}

\section{Characterization of isolated compounds}

The fungus isolated from the Red Sea alga $L i$ agora viscida was identified as Penicillium chrysogenum based on its morphology and authenticated by the molecular analysis of the internal transcript spacer (ITS) region of rDNA containing ITS1 and ITS4, and the intervening 5.8S rDNA gene. The fungus was grown in a static liquid medium. The culture broth was extracted with ethyl acetate, and the organic extract was submitted to a combination of silica gel column chromatography (CC), preparative thin-layer chromatography<smiles>Cc1cc(O)c2c(c1)C(=O)c1cc(O)cc(O)c1C2=O</smiles><smiles>Cc1cc(O)c2c(c1)C(=O)c1cc(O)cc(O)c1C2=O</smiles>

2<smiles>O=C1c2cc(CO)cc(O)c2C(=O)c2cc(O)cc(O)c21</smiles><smiles>Cc1cc(O)c2c(c1)C(=O)c1cccc(O)c1C2=O</smiles><smiles>C/C=C/CCC(=O)c1cc(C)c(O)c(C)c1O</smiles><smiles>C=CC(C)(C)C12C=C(O)C(=O)N1/C(=C/c1cnc[nH]1)C(=O)NC21c2ccccc2N1OC</smiles>
4 5 6<smiles>CC(=O)c1nc2ccccc2c(=O)[nH]1</smiles><smiles>O=c1cc[nH]c(=O)[nH]1</smiles><smiles>CC(C)CC1NC(=O)C(C)NC1=O</smiles><smiles>CC(C)C1NC(=O)C2CCCN2C1=O</smiles>

7

9

10

Fig. 1. Compounds isolated from Penicillium chrysogenum: alatinone (1), emodin (2), $\omega$-hydroxyemodin (3), chrysophanol (4), 2',3'-dihydrosorbicillin (5), meleagrin (6), chrysoginone (7), uracil (8), cyclo-L-Ala-L-Leu (9), and maculosin-5 (10). 
(TLC), and semi-preparative high-performance liquid chromatography (HPLC) to afford twelve known metabolites, 1-12 (Fig. 1). NMR spectroscopy (1D- and 2D-NMR) and mass spectrometry (MS) were extensively used in structural elucidation. The isolated compounds were identified based on the spectral analyses and comparison with literature data.

The presence of peri-hydroxyanthraquinones in compounds 1-4 was detected by TLC on silica gel plates sprayed with $1.0 \%$ vanillin $/ \mathrm{H}_{2} \mathrm{SO}_{4}$ and by their red colour with $5 \% \mathrm{KOH}$ solution, respectively. The NMR spectra of these compounds revealed tricyclic anthraquinones with chelated hydroxy, methyl, and methoxy groups. These compounds were identified as alatinone (1) (Hemlata and Kalidhar, 1993), emodin (2) (Cohen and Towers, 1995), $\omega$-hydroxyemodin (3) (Benfaremo and Cava, 1985), and chrysophanol (4) (Chang et al., 1998). However, this is the first report on the isolation of alatinone (1) from a microorganism. The phenone compound 2',3'-dihydrosorbicillin (5) was obtained by semi-preparative HPLC as a light yellow solid soluble in $\mathrm{MeOH}$ (Maskey et al., 2005).

Alkaloid metabolites $\mathbf{6 - 1 0}$ with substituted nitrogen atoms showed both aromatic (compounds 6-8) and aliphatic (compounds 9 and 10) proton characters in their ${ }^{1} \mathrm{H}$ NMR spectra. The compounds were characterized as meleagrin (6) (Kawai et al., 1984), chrysoginone (7) (Blight and Grove, 1974), uracil (8) (Huang et al., 1995), cyclo-L-Ala-L-Leu (9) (Caesar et al., 1969), and maculosin-5 (10) (Lee et al., 1994). In addition, two unsaturated fatty acids, oleic acid (11) and linoleic acid (12), were isolated from the $n$-hexane fraction (Carballeira et al., 2000).

\section{Antimicrobial activity}

The results of the antimicrobial activity tests of the extract and the isolated pure compounds are shown in Table I. The tested pathogens were found to be resistant to emodin (2), $\omega$-hydroxyemodin (3), and cyclo-L-Ala-L-Leu (9). Candida albicans was sensitive to the extract and meleagrin (6) with inhibition diameters of 18 and $15 \mathrm{~mm}$, respectively. Klebsiella pneumoniae was highly sensitive to the extract and the isolated compounds 2',3'-dihydrosorbicillin (5) and meleagrin (6). Chrysophanol (4), 2',3'-dihydrosorbicillin (5), chrysoginone (7), and maculosin-5 (10) moderately inhibited the growth of Aspergillus niger, Escherichia coli, Bacillus subtilis, and $\mathrm{Ba}$ cillus megaterium.

\section{Anticancer activity}

The ethyl acetate extract and the isolated compounds were evaluated for their in vitro anticancer activity against cancer and normal cell lines using the disk diffusion assay (Table II). As a result of this bioassay, the extract demonstrated some selectivity against colon 38 cells with a zone

Table I. Antimicrobial potential (inhibition zone in $\mathrm{mm}$ ) of the extract and nine compounds isolated from Penicillium chrysogenum in a radial diffusion assay.

\begin{tabular}{|c|c|c|c|c|c|c|c|c|c|c|}
\hline \multirow[t]{2}{*}{ Sample } & \multicolumn{4}{|c|}{ Gram-positive bacteria $^{a}$} & \multicolumn{3}{|c|}{ Gram-negative bacteria $^{a}$} & \multicolumn{3}{|c|}{ Fungi $^{\mathrm{a}}$} \\
\hline & S.a. & B.m. & B.c. & B.s. & E.c. & K.p. & Es.c. & C.a. & A.n. & S.c. \\
\hline Ethyl acetate extract & - & $12 \pm 1.1$ & 8 & 8 & - & $17 \pm 0.5$ & - & $18 \pm 0.1$ & - & - \\
\hline Alatinone (1) & - & 11 & 9 & - & - & 10 & - & 9 & - & - \\
\hline Emodin $(\mathbf{2})$ & - & - & - & - & 9 & - & - & - & - & - \\
\hline$\omega$-Hydroxyemodin (3) & 10 & - & - & - & - & - & - & 8 & - & - \\
\hline Chrysophanol (4) & - & - & - & 10 & - & - & $13 \pm 1.5$ & - & 10 & - \\
\hline 2',3'-Dihydrosorbicillin (5) & - & $14 \pm 1.5$ & - & - & - & $18 \pm 1.1$ & - & - & 11 & - \\
\hline Meleagrin (6) & - & 9 & - & - & - & $19 \pm 2.0$ & - & $15 \pm 2.5$ & - & 11 \\
\hline Chrysoginone (7) & 8 & 12 & - & $15 \pm 1.1$ & - & - & 8 & - & - & 8 \\
\hline Cyclo-L-Ala-L-Leu (9) & - & - & - & - & 12 & - & - & 10 & - & - \\
\hline Maculosin-5 (10) & - & - & 11 & - & - & - & $14 \pm 1.3$ & 11 & - & 10 \\
\hline $\begin{array}{l}\text { Oxytetracycline }(30 \mu \mathrm{g}) \\
\text { (control) }\end{array}$ & 17 & 20 & 10 & 10 & 22 & - & 15 & - & - & - \\
\hline
\end{tabular}

a S.a., Staphylococcus aureus; B.m., Bacillus megaterium; B.c., Bacillus cereus; B.s., Bacillus subtilis, E.c., Enterobacter cloacae; K.p., Klebsiella pneumoniae; Es.c.: Escherichia coli, C.a., Candida albicans; A.n., Aspergillus niger; S.c., Saccharomyces cerevisiae. 
Table II. Cytotoxicity results presented in $\mathrm{zu}^{\mathrm{a}}(200 \mathrm{zu} \bumpeq 6 \mathrm{~mm}$ inhibition) of the extract and compounds isolated from the endophytic Pencillium chrysogenum.

\begin{tabular}{|c|c|c|c|c|c|c|c|}
\hline \multirow[t]{3}{*}{ Sample } & \multirow{3}{*}{$\begin{array}{l}\text { Normal cells } \\
\text { CFU-GM }\end{array}$} & \multirow{2}{*}{\multicolumn{2}{|c|}{ Leukemia }} & \multicolumn{4}{|c|}{ Solid tumours } \\
\hline & & & & \multicolumn{2}{|c|}{ Colon cancer } & \multirow{2}{*}{$\begin{array}{c}\text { Lung cancer } \\
\mathrm{H}-125\end{array}$} & \multirow{2}{*}{$\begin{array}{c}\text { Liver cance } \\
\text { HEP-G2 }\end{array}$} \\
\hline & & L1210 & CCRF-CEM & HCT-116 & $\mathrm{C} 38$ & & \\
\hline Ethyl acetate extract & 250 & 300 & 0 & 250 & 400 & 250 & 250 \\
\hline Alatinone (1) & 50 & 200 & 0 & 50 & 200 & 50 & 150 \\
\hline Emodin (2) & - & 100 & - & 0 & 250 & 0 & 100 \\
\hline$\omega$-Hydroxyemodin (3) & 300 & 400 & 300 & 200 & 350 & 250 & 450 \\
\hline Meleagrin (6) & 650 & 700 & 500 & 450 & 600 & 600 & 600 \\
\hline Oleic acid (11) & - & 200 & - & 200 & 150 & 150 & 300 \\
\hline Linoleic acid (12) & - & 200 & - & 150 & 150 & 200 & 250 \\
\hline
\end{tabular}

a $\mathrm{zu}$, zone units.

Table III. Inhibition of HCV NS3-NS4A protease and human trypsin by the extract and compounds isolated from Penicillium chrysogenum.

\begin{tabular}{|c|c|c|}
\hline \multirow[t]{2}{*}{ Sample } & \multicolumn{2}{|c|}{$\mathrm{IC}_{50}[\mu \mathrm{g} / \mathrm{ml}]$} \\
\hline & HCV PR inhibitory activity (\%) & Trypsin inhibitory activity (\%) \\
\hline Ethyl acetate extract & $20.0 \pm 4.3$ & $>1000$ \\
\hline Alatinone (1) & $100.0 \pm 3.7(370 \mu \mathrm{M})$ & $>1000$ \\
\hline Emodin $(\mathbf{2})$ & $22.5 \pm 1.6(80 \mu \mathrm{M})$ & $450.5 \pm 4.7(1.6 \mathrm{~mm})$ \\
\hline$\omega$-Hydroxyemodin (3) & $10.6 \pm 0.3(30 \mu \mathrm{M})$ & $45.2 \pm 5.1(157 \mu \mathrm{M})$ \\
\hline Chrysophanol (4) & $>1000$ & $\mathrm{Nt}$ \\
\hline 2',3'-Dihydrosorbicillin (5) & $>1000$ & $\mathrm{Nt}$ \\
\hline Meleagrin (6) & $>1000$ & $\mathrm{Nt}$ \\
\hline Chrysoginone (7) & $>1000$ & $\mathrm{Nt}$ \\
\hline Uracil (8) & $>1000$ & $\mathrm{Nt}$ \\
\hline Cyclo-L-Ala-L-Leu (9) & $>1000$ & $\mathrm{Nt}$ \\
\hline Maculosin-5 (10) & $>1000$ & $\mathrm{Nt}$ \\
\hline $\mathrm{HCV}-\mathrm{I}_{2}$ & $1.5 \pm 0.5(1.64 \mu \mathrm{M})$ & $\mathrm{Nt}$ \\
\hline T-I & $\mathrm{Nt}$ & $0.01 \pm 0.4(0.5 \mu \mathrm{M})$ \\
\hline
\end{tabular}

HCV-I $\mathrm{I}_{2}, \mathrm{HCV}$ NS3-NS4A protease inhibitor 2 (positive control for HCV PR); T-I, soybean trypsin-chymotrypsin inhibitor (positive control for trypsin); Nt, not tested.

difference of 150 units compared to the normal cells (CFU-GM) at a concentration of $30 \mu \mathrm{g} /$ disk. Of the compounds in the extract, only $\mathbf{3}$ and $\mathbf{6}$ were shown to have clearly inhibitory activity at $3 \mu \mathrm{g} / \mathrm{disk}$.

\section{HCV NS3-NS4A protease inhibition}

The ethyl acetate extract along with compounds 1-10 isolated from this extract were tested for their inhibitory activity against $\mathrm{HCV}$ PR using HCV NS3-NS4A protease inhibitor 2 as a positive control (Table III). The ethyl acetate extract exhibited potent activity against $\mathrm{HCV}$ NS3-NS4A protease with an $\mathrm{IC}_{50}$ value of $20 \mu \mathrm{g} /$ $\mathrm{ml}$. Compounds $\mathbf{2}$ and $\mathbf{3}$ were strongly inhibitory with $\mathrm{IC}_{50}$ values of 22.5 and $10.6 \mu \mathrm{g} / \mathrm{ml}$, respectively, while compound $\mathbf{1}$ was weakly inhibitory with an $\mathrm{IC}_{50}$ value of $100 \mu \mathrm{g} / \mathrm{ml}$. The selectivity of the ethyl acetate extract and the active compounds for HCV PR was tested by comparison with their ability to inhibit human trypsin. Trypsin is a serine protease similar to HCV PR (Love et al., 1996; Wei et al., 2009). Compound 2 was 20 times more selective as inhibitor of HCV PR than human trypsin (Table III). Although compound 3 inhibited HCV PR more potently than $\mathbf{2}$, it was less selective. It is noteworthy that this is the first report on the inhibition of HCV PR by anthraquinones which warrants further investigation of other members of this widely distributed class of compounds. 

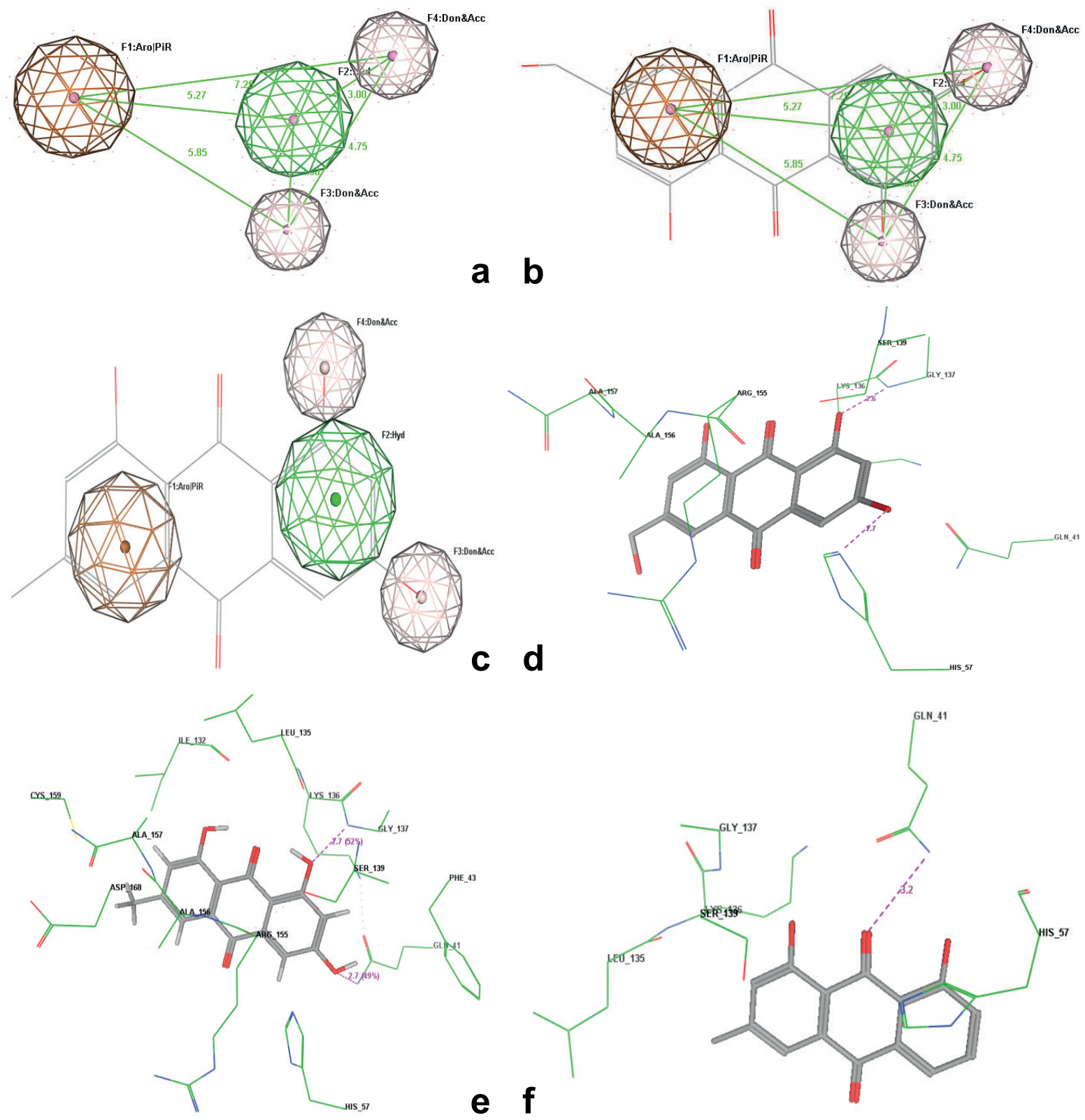

Fig. 2. Pharmacophore model and docking: Requirement of structural features in anthraquinones as HCV protease inhibitors and docking of the isolated compounds to the HCV NS3-NS4A protease active site. H-bonds are represented by dashed lines, H-bonding length is measured in angstrom. (a) Pharmacophore features of anthraquinone, distances between features are given in angstrom. (b) Superimposition of the pharmacophoric features on compound 3. (c) Superimposition of the pharmacophoric features on compound 2. (d) Docking of compound 3. (e) Docking of compound 2. (f) Docking of compound 4. Aro, aromatic; Pir, $\pi$-ring; Hyd, hydrophobic; Don\&Acc, donor and acceptor. 
Due to the lack of any information on the structural requirements of anthraquinones as HCV PR inhibitors, the significant pharmacophoric features of these compounds were determined and verified by docking the active compounds to the HCV PR active site.

\section{Pharmacophore elucidation}

The generated pharmacophore model consists of four essential structural features (Fig. 2a), where the presence of aromatic and hydrophobic moieties in the anthraquinone nucleus is important for activity. In addition, the presence of meta-coupled H-bond donors and/or acceptors is essential for binding to $\mathrm{H}$-bond donors and acceptors in the HCV PR active site (Fig. 2a). Screening of the isolated compounds on this suggested pharmacophore revealed the lack of these features in all compounds except compounds 2 and $\mathbf{3}$ (Figs. $2 \mathrm{~b}$ and $\mathrm{c}$ ).

\section{Docking study}

It is well established that interactions between the HCV PR active site and conventional electrophiles such as aldehydes, ketones, $\alpha$-ketoacids, and $\alpha$-ketoamides, followed by trapping of the resulting covalently bound intermediate by the active site triad (Ser139, His57, and Asp81), will provide effective inhibition (Njoroge et al., 2008). Additionally, it has been reported that the fitting of ligand functional groups to the shallow, solventexposed active site of the protease through other forces, such as van der Waals, aromatic, H-bonding, and hydrophobic interactions, plays an important role in the inhibition of HCV PR (Njoroge et al., 2008). The co-crystal structure ligand $2 \mathrm{~A} 4 \mathrm{Q}$ used in this study inhibits HCV PR by forming a reversible covalent bond between the enzyme active site Ser139 hydroxy and the ketone carbonyl group of the inhibitor (code 2A4Q). This compound also forms multiple H-bonds with Gln41, Gly137, and Ala153 in the protease active site through its amide chain (Chen et al., 2005). There is little information available on the binding of naturally occurring nonpeptidomimetic compounds to HCV PR and no information at all regarding the binding of anthraquinones to $\mathrm{HCV}$ PR (El Dine et al., 2011).

Compound $\mathbf{3}$ is predicted to bind with the meta-coupled phenolic hydroxy groups to Gln 41 and His57, one of the active triad amino acids in the active site, which could be one reason for its higher activity (Fig. 2 d). Compound $\mathbf{2}$ is predicted to form a H-bond between the meta-coupled phenolic hydroxy groups and Gln41 and Gly137 (Fig. 2e). On the other hand, compound 4 binds only to Gln41 through its carbonyl group, while failing to bind to any other amino acid due to the lack of meta-coupled phenolic hydroxy groups (Fig. 2f).

These docking results are in accordance with the proposed pharmacophore model regarding the significance of the hydroxy groups as H-bond donors and/or acceptors (Fig. 2a). Most of the active compounds in this study are predicted to form H-bonds with amino acids other than Ser139, and the distance between the functional group and the hydroxy group of Ser139 was not sufficient to permit the formation of a covalent bond. This may be the reason why these compounds are not as potent as the positive control or the inhibitor used in the docking study (Chen et al., 2005).

\section{Conclusion}

The ethyl acetate extract from the endophytic $P$. chrysogenum has been established here as a source of a variety of natural compounds with diverse biological activities, such as antimicrobial, anticancer, and anti-HCV PR effects. The main constituents of the extract were anthraquinones and nitrogenous compounds.

Anthraquinones are a group of widely distributed natural constituents with diverse pharmacological activities, such as anticancer (Yang et al., 2013), antimicrobial (Rhea et al., 2012), and hepatoprotective effects (Byun et al., 2007). Emodin (2), as an example, exhibited anticancer activity through induction of apoptosis (Hsu and Chung 2012; Liu et al., 2012), antiviral activity against herpes simplex (Xiong et al., 2011), and inhibition of HIV-1 reverse transcriptase (Kharlamova et al., 2009). Moreover, emodin was identified as a potent inhibitor of casein kinase (CK2), a target in neurodegenerative diseases and cancer therapy, with an $\mathrm{IC}_{50}$ value of $2 \mu \mathrm{M}$ (Yim et al., 1999).

Surprisingly, even though there is little if any similarity between the active sites of HCV PR (serine protease), CK2 (protein kinase), and HIV-1 reverse transcriptase, emodin was a potent inhibitor of all these targets. The possible explanation for this finding, as revealed by our pharmacophore model, could be the diversity of the 
functional groups in the emodin molecule. The presence of H-bond donors and acceptors, such as the phenolic hydroxy groups which can bind to the nitrogen atoms of several amino acid residues, e.g. histidine, in the active sites of these enzymes could be cited as an example. In addition, the presence of electrophilic moieties, such as the carbonyl group, is considered important for the attack of amino acids with nucleophilic hydroxy groups, as in serine. Moreover, the rigidity of the molecule and its hydrophobic and aromatic moieties are important for aromatic interactions with amino acids such as phenylalanine. The presence of this wide variety of functional groups makes most anthraquinones promising candidates for enzyme inhibition and small ligand-protein interactions.

Finally, the pharmacophore model proposed here can serve as a tool in the ligand-based virtual screening of other anthraquinones for their possible anti-HCV PR effects.

Thus, we introduce emodin (2) and $\omega$-hydroxyemodin (3) as promising lead HCV PR inhibitors for further semi-synthetic modification aiming at increasing their potency and selectivity.

\section{Material and Methods}

\section{General experimental procedures}

Sephadex LH-20 (Pharmacia, Uppsala, Sweden) and silica gel (60-120 mesh; Qualigens, Mumbai, India) were used for CC. Culture media of Czapek agar and potato dextrose broth were procured from Lab M (Bury, Lancashire, UK). $n$-Hexane, ethyl acetate, and methanol were used for CC. Flash chromatography was carried out on silica gel (230-400 mesh). TLC was performed on Polygram SIL G/UV ${ }_{254}$ plates (Macherey-Nagel, Düren, Germany). Mixtures of methanol and methylene chloride (3:2 and 1:1, v/v) were used as mobile phase for TLC analysis. Compounds were visualized as intense dark blue and yellow coloured spots on TLC plates under UV light. Most of the coloured spots changed their colour after spraying with vanillin $/ \mathrm{H}_{2} \mathrm{SO}_{4}$ followed by heating at $120{ }^{\circ} \mathrm{C}$. UV/Vis spectra were recorded on a Shimadzu model UV-240 spectrometer (Tokyo, Japan). NMR spectra were measured on a Jeol ECA 300 (Tokyo, Japan) $\left({ }^{1} \mathrm{H}, 300 \mathrm{MHz} ;{ }^{13} \mathrm{C}\right.$, $75.4 \mathrm{MHz}$ ) and a Varian Inova 500 (International Equipment Trading Ltd, Vernon Hills, IL, USA) $\left({ }^{1} \mathrm{H}, 500 \mathrm{MHz} ;{ }^{13} \mathrm{C}, 125.7 \mathrm{MHz}\right)$ spectrometer, re- spectively. ESI-mass spectra were recorded on a Finnigan LCQ ion trap mass spectrometer (San Jose, CA, USA).

\section{Enzymes and chemicals}

The Sensolyte ${ }^{\mathrm{TM}} 520 \mathrm{HCV}$ protease assay kit fluorimetric (Lot\# AK71145-1020), HCV NS3NS4A protease, HCV NS3-NS4A protease inhibitor 2 (cat\# 25346), and Sensolyte ${ }^{\mathrm{TM}}$ Green protease assay kit fluorimetric (Lot\# AK71124-1011) were purchased from AnaSpec (San Jose, CA, USA). Soybean trypsin-chymotrypsin inhibitor was purchased from Sigma-Aldrich (St. Louis, MO, USA). Falcon ${ }^{\mathrm{TM}}$ Microtest $^{\mathrm{TM}}$ 384-well $120 \mu \mathrm{l}$ black assay plates (nonsterile, no lid) were purchased from Becton Dickinson (Tokyo, Japan).

\section{Fungal isolation and culture conditions}

The red alga Liagora viscida (Forsskål) C. Agardh was collected from the Egyptian Red Sea at a depth of 5-8 m off the coast of Rass Mohamed (South Sinai, Egypt) in March 2010. The sample was selected solely on the basis of a clean and healthy exterior, and brought to the laboratory in ice. In the laboratory, specimens were washed with sterile water and processed immediately. The sample was identified by the Coral Reef Ecology and Biology Group, National Institute of Oceanography and Fisheries, Suez, Egypt.

After proper washing, samples were cut into 0.5 - to $1-\mathrm{cm}$ pieces, surface-sterilized with $70 \%$ ethanol for $1 \mathrm{~min}$, and rinsed three times with sterile distilled water. The algal pieces were blotted on sterile blotting paper. Each piece was placed in a Petri dish on the surface of solid potato dextrose agar (PDA) medium containing $(\mathrm{g} / \mathrm{l})$ potato $(200)$, glucose (10), and agar (15), at $\mathrm{pH} 7.5$, prepared in $50 \%$ sea water supplemented with penicillin benzyl sodium salt $(0.02 \mathrm{~g} / \mathrm{l})$ to avoid any bacterial growth.

\section{Morphological and molecular identification of the endophytic isolate}

After $1 \mathrm{~d}$ of incubation in PDA medium, sandybrown, velvety colonies were observed. The strain was identified as Penicillium chrysogenum based on the morphological features of its conidiophores, and a voucher specimen of the fungus was deposited at the Microbiology Department, Assiut University, Assiut, Egypt. 
The mycelium was scraped directly from the surface of the PDA culture (1 d old) and weighed. DNA was extracted and purified, using the GenElute $^{\mathrm{TM}}$ DNA isolation kit for genomic DNA (Sigma-Aldrich), by the method of Chomczynski (1993). For identification of the fungal species, the ITS regions ITS1 and ITS4 and the intervening 5.8S rDNA region were amplified and sequenced by electrophoretic sequencing on a 3130-genetic analyzer (Fermentas, Glen Burnie, MD, USA; taq polymerase, dntps) using the GenJET ${ }^{\mathrm{TM}}$ sequencing kit (Sigma-Aldrich). The DNA fragment of the ITS regions was amplified using the polymerase chain reaction (PCR) with the pair of primers ITS1 [5'-GGAAGGG(G/A)TGTATTATTAG-3'] and ITS4 (5'-GTAAAAGTCCTGGTTCCC-3'). Multiple sequence alignment was performed and the molecular phylogeny established using BioEdit (Hall, 1999). According to sequencing similarities and multiple alignment, the fungus was found to be closely related to $P$. chrysogenum strain CBS 306.48 (ac: GU733359.1) with 91\% identity. DNA sequencing was carried out by Sequencer Scientific Bourg El-Arab, Alexanderia, Egypt.

\section{Extraction and isolation of compounds}

The isolated fungus $P$. chrysogenum was cultivated on Czapek's peptone liquid medium containing (g/l) glucose (30), yeast (2), peptone (10), $\mathrm{NaNO}_{3}(3), \mathrm{KH}_{2} \mathrm{PO}_{4}(0.5)$, and $\mathrm{KCl}(0.5)$, in $50 \%$ sea water at room temperature. Twenty one-dayold fermentation broth (12 1) was separated from the fungal mat by filtration. The fungal mycelia were suspended in distilled water for easy blending by a dispersing tool (Ultra Turrax model 25; IKA, Staufen, Germany) at $8000 \mathrm{~min}^{-1}$ and the homogenate was extracted with ethyl acetate. The resultant extract was evaporated to dryness using a rotavapor at $40{ }^{\circ} \mathrm{C}$, followed by de-fatting with $n$-hexane.

The crude extract was chromatographed over a silica gel column using $n$-hexane as starting nonpolar eluent; the polarity was gradually increased with ethyl acetate as polar solvent in the eluent mixture $(5 \%, 10 \%$, until $100 \%$ ethyl acetate, $\mathrm{v} / \mathrm{v})$, followed by methanol/ethyl acetate (1:4 and 1:1, $\mathrm{v} / \mathrm{v}$. The combined fractions were further purified by preparative TLC $\left(\mathrm{CH}_{3} \mathrm{OH} / \mathrm{CH}_{2} \mathrm{Cl}_{2}, 5: 95\right)$ and semi-preparative HPLC using a $\mathrm{C} 18$ column, eluted with acetonitrile/water (90:10, isocratic method, $1.5 \mathrm{ml} / \mathrm{min}$ ), and a Sephadex LH-20 column, eluted with $\mathrm{CH}_{3} \mathrm{OH}, \mathrm{CH}_{3} \mathrm{OH} / \mathrm{CH}_{2} \mathrm{Cl}_{2}$ (1:1 and 2:3), and $\mathrm{CH}_{3} \mathrm{OH} / \mathrm{CH}_{2} \mathrm{Cl}_{2} / n$-hexane (2:2:1), to yield pure compounds 1-12, which were subjected to analysis by mass and NMR spectroscopy.

Alatinone (1,5,7-trihydroxy-3-methylanthraquinone) (1): Orange powder. - Yield: $7 \mathrm{mg}$. - TLC: $R_{\mathrm{f}}=0.76\left(\mathrm{CH}_{3} \mathrm{OH} / \mathrm{CH}_{2} \mathrm{Cl}_{2}, 5: 95\right) .-{ }^{1} \mathrm{H}$ NMR (DMSO- $\left.d_{6}, 600 \mathrm{MHz}\right): \delta=12.05(2 \mathrm{H}, \mathrm{br}, 8-\mathrm{OH})$, $12.0(2 \mathrm{H}, \mathrm{br}, 1-\mathrm{OH}), 7.66(1 \mathrm{H}, \mathrm{br}, \mathrm{H}-4), 7.53(1 \mathrm{H}$, $\mathrm{d}, J=2.3 \mathrm{~Hz}, \mathrm{H}-8), 7.25(1 \mathrm{H}, \mathrm{br}, \mathrm{H}-2), 7.05(1 \mathrm{H}, \mathrm{d}$, $J=2.3 \mathrm{~Hz}, \mathrm{H}-6), 2.53\left(3 \mathrm{H}, \mathrm{s}, 3-\mathrm{CH}_{3}\right) .-{ }^{13} \mathrm{C} \mathrm{NMR}$ $\left(\mathrm{DMSO}-d_{6}, 150 \mathrm{MHz}\right): \delta=189.7$ (C-9), 181.2 (C-10), 163.2 (C-7), 161.4 (C-1), 160.8 (C-5), 148.5 (C-3), 134.4 (C-4a), 132.9 (C-10a), 124.0 (C-2), 120.5 (C-4), 113.5 (C-9a), 112.2 (C-8a), 111.3 (C-6), $111.1(\mathrm{C}-8), 21.4\left(3-\mathrm{CH}_{3}\right) .-(-)$-ESI-MS: $m / z=269(100 \%)[\mathrm{M}-\mathrm{H}]^{-}$.

Emodin (1,3,8-trihydroxy-6-methylanthraquinone) (2): Red powder. - Yield: $26 \mathrm{mg}$. - TLC: $R_{\mathrm{f}}=0.70\left(\mathrm{CH}_{3} \mathrm{OH} / \mathrm{CH}_{2} \mathrm{Cl}_{2}, 5: 95\right) . \quad-{ }^{1} \mathrm{H}$ NMR (DMSO- $\left.d_{6}, 300 \mathrm{MHz}\right): \delta=12.14(2 \mathrm{H}, \mathrm{br}, 1-\&$ 8-OH), $7.39(1 \mathrm{H}, \mathrm{d}, J=1.2 \mathrm{~Hz}, \mathrm{H}-4), 7.09(1 \mathrm{H}, \mathrm{d}$, $J=1.2 \mathrm{~Hz}, \mathrm{H}-2), 6.96(1 \mathrm{H}, \mathrm{d}, J=2 \mathrm{~Hz}, \mathrm{H}-5), 6.19$ $(1 \mathrm{H}, \mathrm{d}, J=2 \mathrm{~Hz}, \mathrm{H}-7), 2.41\left(3 \mathrm{H}, \mathrm{s}, 6-\mathrm{CH}_{3}\right) .-{ }^{13} \mathrm{C}$ NMR (DMSO- $\left.d_{6}, 125.7 \mathrm{MHz}\right): \delta=188.3(\mathrm{C}-9)$, 181.4 (C-10), 164.7 (C-3), 161.2 (C-1/8), 147.4 (C-3), 134.7 (C-10a), 132.6 (C-4a), 123.7 (C-2), 120.0 (C-4), 113.3 (C-9a), 110.3 (C-8a), 107.7 (C-5), 107.4 (C-7), $21.3\left(6-\mathrm{CH}_{3}\right) .-(-)$-ESI-MS: $m / z=269(100 \%)[\mathrm{M}-\mathrm{H}]^{-}$.

$\omega$-Hydroxyemodin (1,3,8-trihydroxy-6-hydroxymethylanthraquinone) (3): Red powder. - Yield: $12 \mathrm{mg}$. - TLC: $R_{\mathrm{f}}=0.72\left(\mathrm{CH}_{3} \mathrm{OH} / \mathrm{CH}_{2} \mathrm{Cl}_{2}, 5: 95\right)$. $-{ }^{1} \mathrm{H}$ NMR (DMSO- $\left.d_{6}, 300 \mathrm{MHz}\right): \delta=12.09(2 \mathrm{H}$, br, 1- \& 8-OH), $7.58(1 \mathrm{H}, \mathrm{d}, J=1.3 \mathrm{~Hz}, \mathrm{H}-4), 7.18$ $(1 \mathrm{H}, \mathrm{d}, J=1.3 \mathrm{~Hz}, \mathrm{H}-2), 7.05(1 \mathrm{H}, \mathrm{d}, J=2.3 \mathrm{~Hz}$, $\mathrm{H}-5), 6.51(1 \mathrm{H}, \mathrm{d}, J=2.3 \mathrm{~Hz}, \mathrm{H}-7), 4.57(2 \mathrm{H}, \mathrm{s}$, 6- $\mathrm{CH}_{2}$ ). $-{ }^{13} \mathrm{C}$ NMR (DMSO- $\left.d_{6}, 125.7 \mathrm{MHz}\right): \delta=$ 189.2 (C-9), 181.3 (C-10), 166.5 (C-3), 164.5 (C-1), 161.3 (C-8), 152.5 (C-3), 134.8 (C-10a), 132.7 (C-4a), 120.7 (C-2), 116.9 (C-4), 114.0 (C-9a), 109.2 (C-5), 108.4 (C-8a), 107.8 (C-7), 61.8 (6$\mathrm{CH}_{2}$ ). - (-)-ESI-MS: $m / z=285(100 \%)[\mathrm{M}-\mathrm{H}]^{-}$.

Chrysophanol (1,8-dihydroxy-3-methylanthraquinone) (4): Orange powder. - Yield: $18 \mathrm{mg}$. - TLC: $R_{\mathrm{f}}=0.68\left(\mathrm{CH}_{3} \mathrm{OH} / \mathrm{CH}_{2} \mathrm{Cl}_{2}, 5: 95\right)$. $-{ }^{1} \mathrm{H}$ NMR (DMSO- $\left.d_{6}, 300 \mathrm{MHz}\right): \delta=12.01(1 \mathrm{H}$, s, OH-8), $11.99(1 \mathrm{H}, \mathrm{s}, \mathrm{OH}-1), 7.74(1 \mathrm{H}, \mathrm{d}, J=$ $7.5 \mathrm{~Hz}, \mathrm{H}-5), 7.61(1 \mathrm{H}, \mathrm{d}, J=7.5 \mathrm{~Hz}, \mathrm{H}-6), 7.55$ 
(1H, br, H-4), 7.23 (1H, d, $J=7.5 \mathrm{~Hz}, \mathrm{H}-7), 7.01$ $\left(1 \mathrm{H}\right.$, br, H-2), $2.41\left(3 \mathrm{H}, \mathrm{s}, 3-\mathrm{CH}_{3}\right) .-{ }^{13} \mathrm{C} \mathrm{NMR}$ (DMSO- $\left.d_{6}, 125.7 \mathrm{MHz}\right): \delta=192.3$ (C-9), 181.8 (C-10), 162.5 (C-1), 162.2 (C-8), 149.1 (C-3), 136.8 (C-6), 133.6 (C-10a), 133.2 (C-4a), 124.3 (C-7), 124.2 (C-2), 121.2 (C-4), 119.8 (C-5), 115.7 (C-9a), 113.5 (C-8a), $22.3\left(3-\mathrm{CH}_{3}\right)$. - (-)-ESI-MS: $\mathrm{m} / z=$ $253(100 \%)[\mathrm{M}-\mathrm{H}]^{-}$.

2',3'-Dihydrosorbicillin (5): Light yellow powder. - Yield: $8 \mathrm{mg}$. - TLC: $R_{\mathrm{f}}=0.6\left(\mathrm{CH}_{3} \mathrm{OH} /\right.$ $\left.\mathrm{CH}_{2} \mathrm{Cl}_{2}, 5: 95\right)$. $-{ }^{1} \mathrm{H}$ NMR (acetone- $d_{6}, 300 \mathrm{MHz}$ ): $\delta=13.0(1 \mathrm{H}, \mathrm{s}, 2-\mathrm{OH}), 7.49(1 \mathrm{H}, \mathrm{s}, \mathrm{H}-6), 5.47(2 \mathrm{H}$, m, H-4'/H-5'), $2.94\left(2 \mathrm{H}, \mathrm{t}, J=7.2 \mathrm{~Hz}, \mathrm{H}_{2}-2^{\prime}\right), 2.31$ $\left(2 \mathrm{H}, \mathrm{m}, \mathrm{H}_{2}-3^{\prime}\right), 2.31\left(3 \mathrm{H}, \mathrm{d}, J=0.8 \mathrm{~Hz}, 5-\mathrm{CH}_{3}\right)$, $2.07\left(3 \mathrm{H}, \mathrm{s}, 3-\mathrm{CH}_{3}\right), 1.59\left(3 \mathrm{H}, \mathrm{m}, \mathrm{H}_{3}-6^{\prime}\right) .-{ }^{13} \mathrm{C}$ NMR (acetone- $\left.d_{6}, 125.7 \mathrm{MHz}\right): \delta=204.6\left(\mathrm{C}-1^{\prime}\right)$, 162.2 (C-2), 160.9 (C-4), 130.9 (C-4'), 129.5 (C-6), 126.2 (C-5'), 116.2 (C-5), 113.2 (C-3), 111.5 (C-1), $37.8\left(\mathrm{CH}_{2}-2^{\prime}\right), 28.1\left(\mathrm{CH}_{2}-3^{\prime}\right), 18.1\left(\mathrm{CH}_{3}-6^{\prime}\right), 16.1$ $\left(5-\mathrm{CH}_{3}\right), 8.1\left(3-\mathrm{CH}_{3}\right) .-(-)$-ESI-MS: $m / z=233$ $(100 \%)[\mathrm{M}-\mathrm{H}]^{-} .-(+)-$ESI-MS: $m / z=257(22 \%)$ $[\mathrm{M}+\mathrm{Na}]^{+}, 487(100 \%)[2 \mathrm{M}+\mathrm{Na}]^{+}$.

Meleagrin (6): White powder. - Yield: $17 \mathrm{mg} .-$ TLC: $R_{\mathrm{f}}=0.26\left(\mathrm{CH}_{3} \mathrm{OH} / \mathrm{CH}_{2} \mathrm{Cl}_{2}, 5: 95\right) .-{ }^{1} \mathrm{H} \mathrm{NMR}$ $\left(\mathrm{CDCl}_{3}, 300 \mathrm{MHz}\right): \delta=12.6(1 \mathrm{H}, \mathrm{s}, 19-\mathrm{NH}), 8.23$ $(1 \mathrm{H}, \mathrm{s}, \mathrm{H}-18), 7.54(1 \mathrm{H}, \mathrm{s}, \mathrm{H}-8), 7.52(1 \mathrm{H}, \mathrm{d}, J=$ $7.6 \mathrm{~Hz}, \mathrm{H}-4), 7.24(1 \mathrm{H}, \mathrm{s}, \mathrm{H}-20), 7.23(1 \mathrm{H}, \mathrm{t}, J=$ $7.6 \mathrm{~Hz}, \mathrm{H}-6), 7.23(1 \mathrm{H}, \mathrm{s}, \mathrm{H}-15), 7.05(1 \mathrm{H}, \mathrm{t}, J=$ $7.6 \mathrm{~Hz}, \mathrm{H}-5), 6.95(1 \mathrm{H}, \mathrm{d}, J=7.6 \mathrm{~Hz}, \mathrm{H}-7), 6.09$ $(1 \mathrm{H}, \mathrm{br}, \mathrm{H}-22), 5.46(1 \mathrm{H}, \mathrm{s}, 14-\mathrm{NH}), 5.02(2 \mathrm{H}, \mathrm{d}$, $J=18 \& 13 \mathrm{~Hz}, \mathrm{H}-23), 3.71\left(3 \mathrm{H}, \mathrm{s}, 1-\mathrm{OCH}_{3}\right), 1.31$ $\left(3 \mathrm{H}, \mathrm{s}, \mathrm{H}_{3}-24\right), 1.19\left(3 \mathrm{H}, \mathrm{s}, \mathrm{H}_{3}-25\right) .-{ }^{13} \mathrm{C} \mathrm{NMR}$ $\left(\mathrm{CDCl}_{3}, 125.7 \mathrm{MHz}\right): \delta=165.7(\mathrm{C}-13), 159.6(\mathrm{C}-$ 9), 159.6 (C-10), 146.9 (C-22), 142.2 (C-7a), 136.7 (C-18), 133.4 (C-3a), 128.6 (C-4/8), 125.9 (C-16), 125.0 (C-6), 123.9 (C-5/20), 113.3 (C-12), 112.0 (C-7), 109.4 (C-23), 108.2 (C-15), 102.6 (C-2), $65.2\left(1-\mathrm{OCH}_{3}\right), 53.8(\mathrm{C}-3), 42.7(\mathrm{C}-21), 24.0(\mathrm{C}-$ 25), 23.7 (C-24). - (-)-ESI-MS: $m / z=432(100 \%)$ $[\mathrm{M}-\mathrm{H}]^{-} .-(+)$-ESI-MS: $m / z=434(100 \%)[\mathrm{M}+$ $\mathrm{H}]^{+}, 456(20 \%)[\mathrm{M}+\mathrm{Na}]^{+}, 867(40 \%)[2 \mathrm{M}+\mathrm{H}]^{+}$, $889(25 \%)[2 \mathrm{M}+\mathrm{Na}]^{+}$.

Chrysoginone [2-acetylquinazolin-4(3H)-one] (7): White powder. - Yield: $14 \mathrm{mg}$. - TLC: $R_{\mathrm{f}}=$ $0.34\left(\mathrm{CH}_{3} \mathrm{OH} / \mathrm{CH}_{2} \mathrm{Cl}_{2}, 5: 95\right) .-{ }^{1} \mathrm{H}$ NMR $\left(\mathrm{CDCl}_{3}\right.$, $300 \mathrm{MHz}): \delta=10.01(1 \mathrm{H}, \mathrm{s}, 3-\mathrm{NH}), 8.35(1 \mathrm{H}, \mathrm{d}, J=$ $8 \mathrm{~Hz}, \mathrm{H}-8), 7.84(1 \mathrm{H}, \mathrm{t}, J=8 \mathrm{~Hz}, \mathrm{H}-5), 7.83(1 \mathrm{H}$, $\mathrm{d}, J=8 \mathrm{~Hz}, \mathrm{H}-7), 7.60(1 \mathrm{H}, \mathrm{t}, J=8 \mathrm{~Hz}, \mathrm{H}-6), 2.71$ $\left(3 \mathrm{H}, \mathrm{s}, 2-\mathrm{COCH}_{3}\right) \cdot-{ }^{13} \mathrm{C} \mathrm{NMR}\left(\mathrm{CDCl}_{3}, 75.4 \mathrm{MHz}\right)$ : $\delta=193.8$ (2-CO), 160.2 (C-4), 147.9 (C-8a), 144.6 (C-3), 134.3 (C-7), 129.3 (C-5), 129.1 (C-8), 126.8
(C-6), $123.4(\mathrm{C}-5 \mathrm{a}), 23.2\left(2-\mathrm{COCH}_{3}\right) \cdot-(+)$-ESIMS: $m / z=211(25 \%)[\mathrm{M}+\mathrm{Na}]^{+}, 399(100 \%)[2 \mathrm{M}$ $+\mathrm{Na}]^{+}, 587(100 \%)[3 \mathrm{M}+\mathrm{Na}]^{+}$.

\section{Antimicrobial activity}

The antifungal and antibacterial activities of the ethyl acetate extract of $P$. chrysogenum and the isolated compounds were determined using the agar diffusion method with $6 \mathrm{~mm}$ paper disks loaded with 100 and $400 \mu \mathrm{g}$ of the extract and each pure compound, respectively (Cosentino et al., 1999). The metabolites were tested against the following indicator strains: Bacillus megaterium, Bacillus cereus, Bacillus subtilis, and Staphylococcus aureus (Gram-positive bacteria) and Enterobacter cloacae, Klebsiella pneumoniae, and Escherichia coli (Gram-negative bacteria), as well as Candida albicans, Saccharomyces cerevisiae, and Aspergillus niger (fungi). Oxytetracycline was used as a positive control.

\section{Cancer cell line assays}

An in vitro cell-based assay, using murine L1210 (leukemia), C38 (colon), and CFU-GM (normal) cells and human HCT-116 (colon), H-125 (lung), CCRF-CEM (leukemia), and HEP-G2 (liver) cells, was employed to assess the general and differential cytotoxicity of the pure compounds (Valeriote et al., 2002). Samples were dissolved in $250 \mu \mathrm{l}$ of dimethyl sulfoxide (DMSO), and 15$\mu \mathrm{l}$ aliquots were applied in duplicate to cellulose disks in agar plates containing the respective cells. After a period of incubation, the zone of cell colony inhibition $(z)$ was measured from the edge of each disk to the edge of colony growth, and expressed as zone units (zu), where $200 \mathrm{zu} \triangleq 6 \mathrm{~mm}$. General cytotoxic activity for a given sample was defined as an antiproliferation zone of $300 \mathrm{zu}$ or greater. The differential cytotoxicity of a pure compound was expressed by observing a zone differential of 250 units or greater between any solid tumour cell (murine colon C38, human colon HCT-116, human lung H-125, human liver HEPG2) and either leukemia cells (murine L1210 or human CCRF-CEM) or normal cells (CFU-GM).

\section{Assay for determination of $\mathrm{HCV}$ protease inhibitory activity}

Samples of $2 \mu \mathrm{l}$ of each compound dissolved in DMSO were placed in each well of a 384-well 
microplate, then $8 \mu \mathrm{l}$ of recHCV PR $(0.5 \mu \mathrm{g} / \mathrm{ml})$ were added, and the plate was briefly agitated. Finally, $10 \mu \mathrm{l}$ of the freshly prepared substrate [Ac-Asp-Glu-Dap (QXLTM520)-Glu-Glu-AbuCOO-Ala-Ser-Cys(5-FAMsp)- $\mathrm{NH}_{2}$ ] were added with sequential rotational shaking. The reaction mixture was incubated for $30 \mathrm{~min}$ at $37^{\circ} \mathrm{C}$. The fluorimetric analyses were performed on an automated TECAN GENios plate reader (Männedorf, Switzerland) with excitation wavelength at $485 \mathrm{~nm}$ and emission wavelength at $530 \mathrm{~nm}$. Each compound was tested in triplicate. HCV PR inhibition (\%) was calculated using the following equation:

inhibition $(\%)=\left(F_{\text {substrate }}-F_{\text {test }}\right) \cdot 100 / F_{\text {substrate }}$,

where $F_{\text {substrate }}$ is the fluorescence of the substrate and enzyme without test compounds, and $F_{\text {test }}$ is the fluorescence of the assay mixture with the added compound.

\section{Green protease assay}

Compounds 1-10 were dissolved in DMSO ( $2.5 \mu \mathrm{l}$; final content, $10 \%, \mathrm{w} / \mathrm{v})$ and placed in the wells of a 384-well microplate. Then $17.5 \mu \mathrm{l}$ of assay buffer and $2.5 \mu \mathrm{l}$ of trypsin $(0.1 \mathrm{U} / \mu \mathrm{l})$ were added and the plate was briefly agitated. Finally, $2.5 \mu \mathrm{l}$ of the freshly diluted protease substrate $\mathrm{Hi}-$ Lyte Fluor ${ }^{\mathrm{TM}}$ 488-labeled casein were added under sequential rotary shaking and the mixture incubated at $37^{\circ} \mathrm{C}$ for $30 \mathrm{~min}$. The positive control was the soybean trypsin-chymotrypsin inhibitor. Inhibition was calculated as for HCV.

\section{Pharmacophore elucidation for the HCV PR inhibitors}

The pharmacophore model was generated using the pharmacophore elucidation function of MOE software 10/2008 (Chemical Computing Group, Montreal, Canada). Prior to running the pharmacophore elucidation, a database of all isolated molecules and their $\mathrm{IC}_{50}$ values was prepared. The $3 \mathrm{D}$ conformations of the compounds were generated using the conformation import function of the software with the default MMFF94x forcefield for energy minimization. In the pharmaco- phore elucidation function the activity field was adjusted to the respective $\mathrm{IC}_{50}$. The features used were Aro/Pir with radius $1.4 \AA$, Hyd (1.4 $\mathrm{A})$, Don and Acc $(1.0 \AA)$, Cat and Ani $(1.0 \AA)$, and O2 (1.4 $\AA$ ) (for abbreviations see legend to Fig. 2). The query cluster was adjusted to 1.25 and conformation to As-Is.

\section{Docking study}

The docking study was carried out using MOE software 10/2008. The crystal structure of HCV NS3-NS4A protease (2A4Q) was downloaded from the protein data bank (www.pdb.org). The 3D structures of the tested compounds were generated using the ligx function of the MOE program followed by energy minimization of the generated structures. The crystal structure of HCV PR was prepared for the docking study using the protonate $3 \mathrm{D}$ function adjusting the temperature to $300 \mathrm{~K}$ and the $\mathrm{pH}$ value to 7 . The electrostatic functional form was used for calculation; electrostatic interactions were computed using GB/VI (generalized born/volume integral formalism) between two atoms if their separation distance was smaller than the cutoff value of $10 \AA$. The electrostatic constants of the solute and solvent were set to 1 and 80 , respectively. The van der Waals forces were set to 800R3. The energy was minimized using the MMFF94x force field. The active site was detected using the surface and mapping function of the program. Docking was carried out by setting the placement to triangle matcher, rescoring 1 to London $\mathrm{dG}$ and its retain to 10 , refinement to force field and rescoring 2 to none, and its retain to 10 . The parameters were selected as they gave the best redocking result for the co-crystal ligand with the root mean square deviation (RMSD) equal to $0.5 \AA$.

\section{Acknowledgement}

The authors thank Prof. Fred Valeriote, Henry Ford Cancer Health System, Detroit, MI, USA, for the tests with the cell lines. This work was supported by a Basic and Applied Research Grant from the Egyptian Science and Technological Development Fund (STDF, Grant No. 990). 
Benfaremo N. and Cava M. P. (1985), Studies in anthracycline synthesis: simple Diels-Alder routes to pachybasin, $\omega$-hydroxypachybasin, aloe-emodin, and fallacinol. J. Org. Chem. 50, 139-141.

Blight M. M. and Grove J. F. (1974), New metabolic products of Fusarium culmorum: toxic trichothec9-en-8-ones and 2-acetylquinazolin-4(3H)-one. J. Chem. Soc. Perkin Trans. 10, 1691-1693.

Bringmann G., Lang G., Gulder T. A. M., Tsuruta H., Muhlbacher J., Maksimenka K., Steffens S., Schaumann K., Stohr R., Wiese J., Imhoff J. F., PerovicOttstadt S., Boreikod O., and Muller W. E. G. (2005), The first sorbicillinoid alkaloids, the antileukemic sorbicillactones A and B, from a sponge-derived Penicillium chrysogenum strain. Tetrahedron 61, 7252-7265.

Byun E., Jeong G.-S., An R.-B., Li B., Lee D.-S., Ko E.K., Yoon K.-H., and Kim Y.-C. (2007), Hepatoprotective compounds of Cassiae semen on tacrine-induced cytotoxicity in Hep G2 cells. Korean J. Pharmacogn. 38, 400-402.

Caesar F., Jansson K. K., and Mutschler E. E. (1969), Nigragillin, a new alkaloid from the Aspergillus niger group. 1. Isolation and structure clarification of nigragillin and a dioxopiperazine. Pharm. Acta Helv. 44, 676-690.

Carballeira N. M., Pagán M., Shalabi F., Nechev J. T., Lahtchev K., Ivanova A., and Stefanov K. (2000), Two novel iso-branched octadecenoic acids from a Micrococcus species. J. Nat. Prod. 63, 1573-1575.

Chang S., Park Y., Chai S., Kim I., Seo Y., Cho K., and Shin J. (1998), Anthraquinones and sterols from the Korean marine Echiura Urechis unicintus. J. Korean Chem. Soc. 42, 64-68.

Chen K. X., Njoroge F. G., Prongay A., Pichardo J., Madison V., and Girijavallabhan N. (2005), Synthesis and biological activity of macrocyclic inhibitors of hepatitis $\mathrm{C}$ virus (HCV) NS3 protease. Bioorg. Med. Chem. Lett. 15, 4475-4478.

Chomczynski P. (1993), A reagent for the single-step simultaneous isolation of RNA, DNA and proteins from cell and tissue samples. BioTechniques 15, $532-534$.

Cohen P. A. and Towers G. H. N. (1995), The anthraquinones of Heterodermia obscurata. Phytochemistry 40, 911-915.

Cosentino S., Tuberoso C. I. G., Pisano B., Satta M., Mascia V., Arzedi E., and Palmas F. (1999), In-vitro antimicrobial activity and chemical composition of Sardinian Thymus essential oils. Lett. Appl. Microbiol. 29, 130-135.

De Francesco R. and Carfi A. (2007), Advances in the development of new therapeutic agents targeting the NS3-4A serine protease or the NS5B RNA-dependent RNA polymerase of the hepatitis $\mathrm{C}$ virus. Adv. Drug Deliv. Rev. 59, 1242-1262.

De Hoog G. S., Guarro J., Figueras M. J., and Gene J. (2000), Atlas of Clinical Fungi, 2nd ed. Centraalbureau voor Schimmelcultures, Utrecht, The Netherlands and Universitat Rovira i Virgili, Reus, Spain, p. 1124.

El Dine R. S., Abdel Monem A. R., El-Halawany A. M., Hattori M., and Abdel-Sattar E. (2011), HCV$\mathrm{NS} 3 / 4 \mathrm{~A}$ protease inhibitory iridoid glucosides and dimeric foliamenthoic acid derivatives from Anarrhinum orientale. J. Nat. Prod. 74, 943-948.

Elander R. P. (2003), Industrial production of $\beta$-lactam antibiotics. Appl. Microbiol. Biotechnol. 61, 385-392.

Gale M. and Foy E. M. (2005), Evasion of intracellular host defence by hepatitis $\mathrm{C}$ virus. Nature 436, 939-945.

Gao S. S., Li X. M., Li C. H., Proksch P., and Wang B. G. (2011), Penicisteroids A and B, antifungal and cytotoxic polyoxygenated steroids from the marine algaderived endophytic fungus Penicillium chrysogenum QEN-24 S. Bioorg. Med. Chem. Lett. 21, 2894-2897.

Hall T. A. (1999), BioEdit: a user-friendly biological sequence alignment editor and analysis program for Windows 95/98/NT. Nucleic Acids Symp. Ser. 41, 95-98.

Hemlata and Kalidhar S. B. (1993), Alatinone, an anthraquinone from Cassia alata. Phytochemistry 32, $1616-1617$

Hsu S.-C. and Chung J.-G. (2012), Anticancer potential of emodin. BioMedicine (Netherlands) 2, 108-116.

Huang Q., Tezuka Y., Hatanaka Y., Kikuchi T., Nishi A., and Tubaki K. (1995), Studies on metabolites of mycoparasitic fungi. III. New sesquiterpene alcohol from Trichoderma koningii. Chem. Pharm. Bull. 43, 1035-1038.

Kawai K., Nozawa K., Nakajima S., and Iitaka Y. (1984), Studies on fungal products. VII. The structures of meleagrin and 9-O-p-bromobenzoylmeleagrin. Chem. Pharm. Bull. 32, 94-98.

Kharlamova T., Esposito F., Zinzula L., Floris G., Cheng Y.-C., Ginger E. D., and Tramontano E. (2009), Inhibition of HIV-1 ribonuclease $\mathrm{H}$ activity by novel frangula-emodine derivatives. Med. Chem. 5, 398-410.

Laatsch H. (2006), Marine bacterial metabolites. In: Frontiers in Marine Biotechnology (Proksch P. and Muller W. E. G., eds.). Horizon Bioscience, Norfolk, UK, pp. 225-288.

Lee H. B., Choi Y. C., and Kim S. U. (1994), Isolation and identification of maculosins from Streptomyces rochei 87051-3. Agric. Chem. Biotechnol. 37, 339-342.

Lin Z. J., Wen J. N., Zhu T. J., Fang Y. C., Gu Q. Q., and Zhu W. M. (2008), Chrysogenamide A from an endophytic fungus associated with Cistanche deserticola and its neuroprotective effect on SH-SY5Y cells. J. Antibiot. 61, 81-85.

Liu J.-X., Zhang J.-H., Li H.-H., Laia F.-J., Chen K.J., Chen H., Luo J., Guo H.-C., Wang Z.-H., and Lin S.-Z. (2012), Emodin induces Panc-1 cell apoptosis via declining the mitochondrial membrane potential. Oncol. Rep. 28, 1991-1996.

Love R. L., Parge H. E., Wickersham J. A., Hoastomsky Z., Habiuka N., Moomaw E. W., Adachi T., and Hostomska Z. (1996), The crystal structure of hepatitis C virus NS3 protease reveals a trypsin-like fold and a structural zinc binding site. Cell 87, 331-342.

Maskey P., Grün-Wollny I., and Laatsch H. (2005), Sorbicillin analogues and related dimeric compounds from Penicillium notatum. J. Nat. Prod. 68, 865-870.

Meng L., Sun P., Tang H., Li L., Draeger S., Schulz B., Krohn K., Hussain H., Zhang W., and Yi Y. (2011), Endophytic fungus Penicillium chrysogenum, a new source of hypocrellins. Biochem. Syst. Ecol. 39, $163-165$. 
Njoroge F. G., Chen K. X., Shih N. Y., and Piwinski J. J. (2008), Challenges in modern drug discovery: a case study of boceprevir, an HCV protease inhibitor for the treatment of hepatitis $\mathrm{C}$ virus infection. Acc. Chem. Res. 41, 50-59.

Rhea J., Craig Hopp D., Rabenstein J., Smith C., Lucas S., Romari K., Clarke M., Francis L., Irigoyen M., Luche M., Carr G. J., and Mocek U. (2012), 5-Hydroxy ericamycin, a new anthraquinone with potent antimicrobial activity. J. Antibiot. 65, 623-625.

Singh S. B., Zink D. L., Guan Z., Collado J., Pelaez F., Felock P. J., and Hazuda D. J. (2003), Isolation, structure, and HIV-1 integrase inhibitory activity of xanthoviridicatin $\mathrm{E}$ and $\mathrm{F}$, two novel fungal metabolites produced by Penicillium chrysogenum. Helv. Chim. Acta 86, 3380-3385.

Tsantrizos Y. S. (2008), Peptidomimetic therapeutic agents targeting the protease enzyme of the human immunodeficiency virus and hepatitis $\mathrm{C}$ virus. Acc. Chem. Res. 41, 1252-1263.

Valeriote F., Grieshaber C. K., Media J., Pietraszkiewicz H., Hoffmann J., Pan M., and McLaughlin S. (2002),
Discovery and development of anticancer agents from plants. J. Exp. Ther. Oncol. 2, 228-236.

Wei Y., Ma C. M., and Hattori M. (2009), Synthesis of dammarane type triterpene derivatives and their ability to inhibit HIV and HCV proteases. Bioorg. Med. Chem. 17, 3003-3010.

Xiong H.-R., Luo J., Hou W., Xiao H., and Yang Z.-Q. (2011), The effect of emodin, an anthraquinone derivative extracted from the roots of Rheum tanguticum, against herpes simplex virus in vitro and in vivo. J. Ethnopharmacol. 133, 718-723.

Yang X., Chou G., Ji L., Han L., and Zhu E. (2013), Anthraquinones from the roots of Knoxia valerianoides and their anticancer activity. Lat. Am. J. Pharm. 32, 96-100.

Yim H., Lee Y. H., Lee C. H., and Lee S. K. (1999), Emodin, an anthraquinone derivative isolated from the rhizomes of Rheum palmatum, selectively inhibits the activity of casein kinase II as a competitive inhibitor. Planta Med. 65, 9-13. 